\title{
Stavovi studenata Zdravstvenog veleučilišta o cijepljenju
}

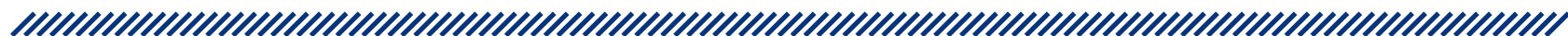

\author{
1 Anna Pierobon \\ 2 Mirjana Lana Kosanović Ličina \\ 1 Zdravstveno veleučilište u Zagrebu, Mlinarska cesta 38, \\ Zagreb \\ 2 Nastavni zavod za javno zdravstvo „Dr. Andrija Štampar”, \\ Mirogojska cesta 16, Zagreb
}

\section{Sažetak}

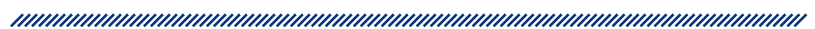

Imunoprofilaksa je umjetno stvaranje imunosti. Provođenje imunoprofilakse vrši se na dva načina, a to su cijepljenje (aktivna imunizacija) i unošenje imunoglobulina (pasivna imunizacija). Aktivna imunizacija ili cijepljenje jest postupak unošenja specifičnog antigena u organizam koji stimulira razvoj specifične obrane prema određenom uzročniku zarazne bolesti. Cijepljenje je dokazano najuspješnija intervencija suvremene medicine i temeljno je ljudsko pravo. Provođenjem cijepljenja u svijetu se znatno smanjio morbiditet i mortalitet u populaciji. U Hrvatskoj se cijepljenje djece i odraslih vrši prema Programu obveznog cijepljenja. Cjepiva se od rođenja primaju u određenim razdobljima života te se neka primaju u jednoj, a neka u više doza. Procijepljenost je u Hrvatskoj na zadovoljavajućoj razini unatoč opadanju postotka procijepljenosti u zadnjih nekoliko godina. Cilj i svrha ovog istraživanja bili su uvidjeti stavove studenata Zdravstvenog veleučilišta (ZVU) o cijepljenju. Uzorak je sadržavao 281 ispitanika. Ispitanici su bili studenti svih smjerova, sve tri godine Zdravstvenog veleu- čilišta (sanitarno inženjerstvo, sestrinstvo, medicinskolaboratorijska dijagnostika, radiologija, radna terapija). Rezultati istraživanja pokazali su da svi studenti imaju pozitivan stav o cijepljenju, što je dobar rezultat s obzirom na to da su svi smjerovi zdravstvenog tipa te da im je edukacija o cijepljenju na visokom nivou.
Ključne riječi: cijepljenje, cjepiva, procijepljenost, stavovi studenata

Datum primitka: 13.10.2020.

Datum prihvaćanja: 30.12.2020.

https://doi.org/10.24141/1/7/1/9

Adresa za dopisivanje:

Anna Pierobon

A: Ploštine 28, Pakrac

E-pošta: annapierobon99@gmail.com

T: +385995721313 


\section{Uvod}

Na zdravstveno stanje ljudi u svijetu, kao i u Hrvatskoj, u zadnjih nekoliko desetljeća najvažniju pozitivnu ulogu imale su dvije higijenske i jedna medicinska mjera. Higijenske su mjere zdravstveno ispravna voda i zdravstveno ispravna hrana. Najvrjednija, najvažnija, najkvalitetnija medicinska mjera koju današnja medicina može pružiti jest cijepljenje kao jedina mjera okrenuta očuvanju zdravlja, a ne liječenju bolesti. U hijerarhiji izvrsnosti medicinskih mjera i postupaka cijepljenje je na prvom mjestu, a tek nakon toga razni kurativni postupci. ${ }^{1}$

Imunoprofilaksa je umjetno stvaranje imunosti. Može se provoditi na dva načina: cijepljenjem (aktivna zaštita) i unošenjem imunoglobulina (pasivna zaštita). ${ }^{2}$ Aktivna imunizacija ili cijepljenje jest postupak unošenja specifičnih antigena u organizam, čime se sam organizam stimulira da razvije specifičnu obranu prema određenoj zaraznoj bolesti. Pasivnom imunizacijom unose se već gotova protutijela kojima želimo postići zaštitu od određenih vrlo teških i smrtonosnih zaraznih bolesti. ${ }^{3}$

Cjepiva se dijele na razne načine. Postoji podjela prema namjeni, koja dijeli cjepiva na ona protiv bakterija, virusa ili drugih mikroorganizama. Međutim, najčešća je podjela na cjepiva koja se sastoje od živih, ali oslabljenih (atenuiranih) uzročnika bolesti i na ona koja se sastoje od mrtvih bakterija i virusa ili njihovih dijelova. ${ }^{4}$ Živa su cjepiva npr. cjepiva protiv tuberkuloze, mumpsa, poliomijelitisa, rubeole i ospica. Neživa cjepiva ona su koja sadrže inaktivirane mikroorganizme, kao npr. cjepivo protiv hripavca, toksini difterije i tetanusa, topivi kapsularni materijal pneumokoka, meningokoka i Haemophilus influenzae tipa b. Neka od neživih cjepiva mogu se dobiti i genetičkim inženjerstvom izdvojenih dijelova DNA-a virusa kao što je cjepivo protiv hepatitisa B. ${ }^{5}$

Nadalje, cjepiva koja se daju samostalno samo za jednu određenu bolest nazivaju se monovalentna cjepiva. Polivalentna cjepiva kombinirana su cjepiva protiv više vrsta bolesti. Korisna su jer se broj pojedinačnih parenteralnih (ubodom u mišić ili pod kožu) primjena znatno smanjuje. Ovakvim se kombiniranim cjepivima jednim ubodom zaštićuje od tri, četiri, pet odnosno šest zaraznih bolesti. Sva kombinirana cjepiva imaju neke zajedničke karakteristike. Imunogenost tih cjepiva za svaku pojedinačnu komponentu jednaka je učinkovitosti cjepiva kada se primjenjuju pojedinačno $i$, prema istraživanjima, iznosi oko $90 \%$. Također, ukupna učestalost nuspojava nije veća od one koja se javlja kod primjene svakog pojedinačnog cjepiva. ${ }^{4}$

Osnovni su sastojci cjepiva antigeni. Antigeni su specifična strana tijela koja izazivaju imunosni odgovor organizma. Prema antigenima organizam stvara specifična protutijela koja su proizvodi limfocita, obrambenih stanica organizama, koji ciljano uništavaju mikroorganizme. Osim individualne zaštite koju postižemo cijepljenjem, optimalnim programom cijepljenja i njegovom provedbom postižemo kolektivnu imunost (za bolesti koje se prenose s čovjeka na čovjeka, ako se postigne dovoljan obuhvat populacije cijepljenjem, prijenos bolesti bit će prekinut - imuni pojedinci zaštitit će neimune). ${ }^{6}$

Osobe koje su zaslužne za početak cijepljenja te njegovo osmišljavanje velikim su dijelom Edward Jenner i Louis Pasteur. Edward Jenner prvi je inokulirao Jamesa Phippsa kravljim boginjama te je taj postupak nazvao vakcinacijom prema latinskoj riječi vacca, što znači krava. ${ }^{7}$ Veliki doprinos uvođenju cijepljenja dao je i Louis Pasteur, koji je osmislio prvo živo, oslabljeno (atenuirano) cjepivo protiv kolere peradi. Nakon toga napravio je i cjepivo protiv bjesnoće. Ostali znanstvenici, potaknuti njihovim radom, napravili su mrtva cjepiva protiv kuge, kolere i tifusa. ${ }^{6}$

Danas je u Republici Hrvatskoj cijepljenje obvezno protiv tuberkuloze, difterije, tetanusa, hripavca, dječje paralize, hepatitisa B, Haemophilus influenzae tipa B, pneumokoka, ospica, zaušnjaka i rubeole te je propisano Programom obveznog cijepljenja, a regulirano je Zakonom o zaštiti pučanstva od zaraznih bolesti (NN 130/17). Također u RH postoji i Program imunizacije, seroprofilakse i kemoprofilakse za posebne skupine stanovništva (kronične bolesnike, imunokompromitirane, profesionalno izložene i dr.) i putnike. ${ }^{8}$

Uobičajene nuspojave koje se javljaju nakon cijepljenja blage su i prolaze spontano nakon cijepljenja. Kod cjepiva koja se primjenjuju kod masovnog procjepljivanja populacije rijetko se javljaju teže nuspojave. Teže su nuspojave npr. reaktivni artritis, anafilaktička reakcija (sustavna alergijska reakcija) ili Arthusova reakcija (lokalna alergijska reakcija). Ozbiljne nuspojave javljaju se vrlo rijetko (u manje od 0,01\% cijepljenih osoba). ${ }^{9}$ Mnogi ljudi svoju djecu ne žele cijepiti iz straha od nuspojava te pojave bolesti poput multiple skleroze i autizma, no provedena su brojna medicinski valjana istraživanja na velikom uzorku koja opovrgavaju ikakvu vezu cijepljenja s nastankom tih bolesti. ${ }^{10}$

Istraživanje ovog tipa provodio je i student Zdravstvenog veleučilišta, uspoređujući znanje i stavove studenata Agronomskog fakulteta i studenata Zdravstvenog veleučilišta. ${ }^{11}$ Osim u Hrvatskoj, slična istraživanja proveli su i studenti u Srbiji. ${ }^{12}$ 


\section{Cilj rada}

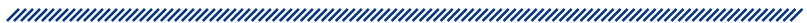

Cilj i svrha ovog istraživanja jesu istražiti stavove studenata Zdravstvenog veleučilišta o cijepljenju te razlikuje li se ono ovisno o smjeru i godini studiranja.

\section{Ispitanici i metode}

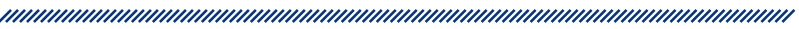

$\mathrm{U}$ ispitivanju je sudjelovao 281 student, a ukupan je broj studenata na svim godinama i smjerovima 1391. Od ukupno 320 studenata sestrinstva u ispitivanju ih je sudjelovalo 82 (26\%), dok je od ukupno 189 studenata sanitarnog inženjerstva sudjelovalo 62 (33\%). Studij fizioterapije ima ukupno 390 studenata, a u ispitivanju je sudjelovalo 56 studenata (14\%). Studij medicinsko-laboratorijske dijagnostike ukupno ima 174 studenta te ih je u ispitivanju sudjelovalo 39 (22,4 \%). Studij radiološke tehnologije ima ukupno 269 studenata te ih je $u$ ispitivanju sudjelovalo $11(4,1 \%)$. Sa studija radne terapije u istraživanju je sudjelovao 31 student od ukupno 149 (0,21\%). Ukupno je sudjelovalo 247 (87,9\%) sudionika ženskog spola i $34(12,1 \%)$ sudionika muškog spola. Najviše je sudionika u dobi od 20 do 21 godine, njih 141, a najmanje studenata u dobi od 24 do 25 godina. Postotak je studenata s prve, druge i treće godine podjednak. U ispitivanju je sudjelovalo $99(35,2 \%)$ studenata s prve godine, 87 (31\%) studenata s druge godine i $95(33,8 \%)$ studenata s treće godine.

\begin{tabular}{|c|c|c|}
\hline \multicolumn{3}{|c|}{ Tablica 1. Smjer studiranja } \\
\hline SMJER & $\begin{array}{c}\text { BROJ } \\
\text { SUDIONIKA }\end{array}$ & $\%$ \\
\hline Sestrinstvo & 82 & 29,2 \\
\hline Sanitarno inženjerstvo & 62 & 22,1 \\
\hline Fizioterapija & 56 & 19,9 \\
\hline $\begin{array}{c}\text { Medicinsko-laboratorijska } \\
\text { dijagnostika }\end{array}$ & 39 & 13,9 \\
\hline Radna terapija & 31 & 11 \\
\hline Radiološka tehnologija & 11 & 3,9 \\
\hline Ukupno & 281 & 100 \\
\hline
\end{tabular}

\begin{tabular}{|c|c|c|}
\hline \multicolumn{3}{|c|}{ Tablica 2. Godina studiranja } \\
\hline GODINA & BROJ SUDIONIKA & $\%$ \\
\hline STUDIRANJA & 99 & 35,2 \\
\hline 1. & 87 & 31 \\
\hline 2. & 95 & 33,8 \\
\hline 3. & 281 & 100 \\
\hline
\end{tabular}

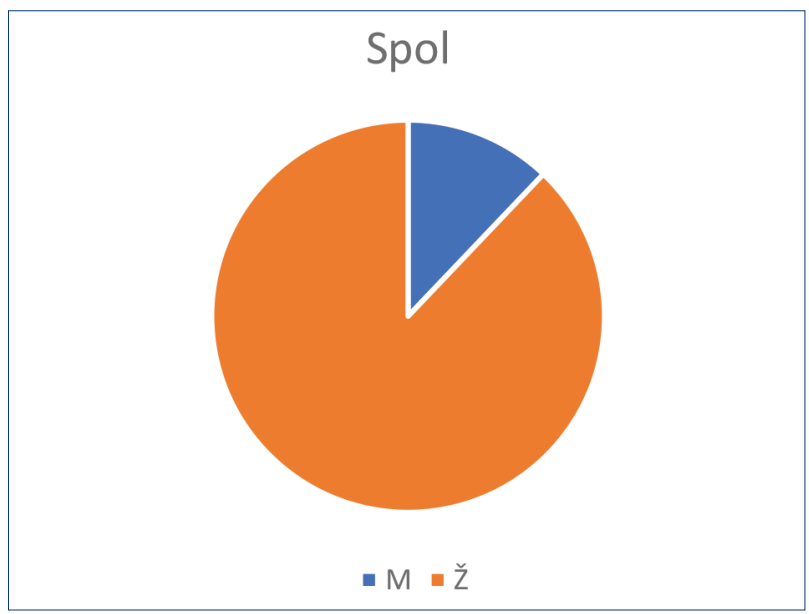

Slika 1. Spol ispitanika

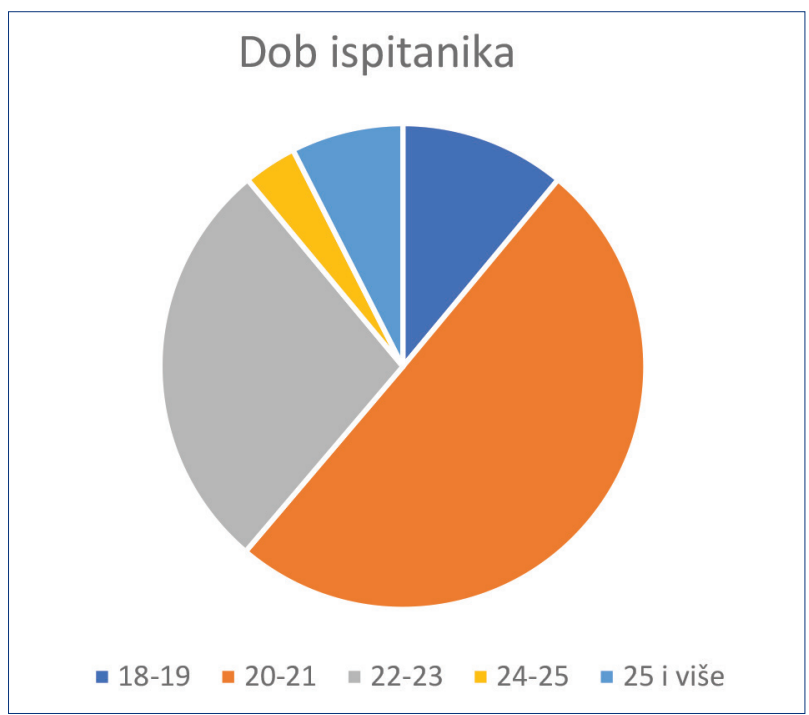

Slika 2. Dob ispitanika

$\mathrm{U}$ istraživanju je primijenjen anonimni anketni upitnik koji su svi ispitanici ispunjavali dobrovoljno, putem web-sučelja. Upitnik se sastojao od četiri dijela. U prvom dijelu ispitivale su se opće informacije o ispitanicima kao što su neke demografske karakteristike sudionika (spol, godina rođenja) te smjer studiranja i godina studija. U ostalim dijelovima ispitivali su se stavovi i pret- 
postavke o cijepljenju, uz primjenu Likertove skale kako bi se najbolje procijenili stavovi studenata o sigurnosti cjepiva, o nuspojavama te o obvezi cijepljenja. Skala je sadržavala sedam tvrdnji i pet mogućih odgovora. Ispitanici su na ponuđene tvrdnje mogli odgovoriti jednim od pet ponuđenih odgovora. Ponuđeni odgovori bili su: 1 - uopće se ne slažem, 2 - uglavnom se ne slažem, 3 - ne mogu se odlučiti, 4 - uglavnom se slažem i 5 - u potpunosti se slažem. Tvrdnje su sadržavale činjenice o cjepivima, primjerice „Cjepiva su korisna” i „Cjepiva su sigurna".

Prikupljanje podataka trajalo je mjesec dana uz slanje tri podsjetnika predstavnicima godina kako bi se povećao broj ispitanika.

\section{Rezultati}

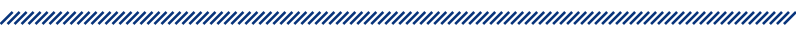

Od ukupnog broja sudionika ovog istraživanja, 64,4 \% (181) studenata je imalo pozitivan stav o cijepljenju, dok je $24,6 \%$ (69) studenata imalo uglavnom pozitivan stav o cijepljenju. Nekolicina ispitanika izrazila je uglavnom negativan ( $8-2,8 \%$ ) ili negativan $(4-1,4 \%)$ stav te je određeni postotak studenata iskazao neodređeni (niti pozitivan niti negativan) stav o cijepljenju.

Stavove studenata o cijepljenju i cjepivima ocjenjivali smo primjenom Likertove skale. Od ukupnog se broja sudionika 192 (68,3\%) u potpunosti slaže da su cjepiva korisna, a $77(27,4 \%)$ da su cjepiva sigurna. Da su cjepi- va sigurna uglavnom se slaže većina studenata. Negativan ili uglavnom negativan stav o ove dvije tvrdnje imala je nekolicina studenata, oko $2 \%$, što je zanemarivo s obzirom na ukupan broj sudionika. 30,2 \% studenata odgovorilo je da se u potpunosti slaže s tvrdnjom da cjepiva imaju nizak rizik teških nuspojava te se gotovo isti postotak studenata $(33,8 \%)$ uglavnom slaže s tom tvrdnjom. Studenata koji imaju neodređen stav prema ovoj tvrdnji bilo je $25,6 \%$, a onih koji se uglavnom ne slažu s tom tvrdnjom 6,8\%. Na tvrdnju „Bojim se mogućih nuspojava cijepljenja” $32,4 \%$ studenata odgovorilo je da se uglavnom ne slaže, a $28,1 \%$ da se uopće ne slaže, 9,3\% studenata u potpunosti se slaže s tvrdnjom da se boji mogućih nuspojava, dok je 13,5\% neodređenog stava. Da cijepljenje mora ostati obvezno u potpunosti se slaže 206 studenata, što je 73,3 \% ukupnog broja sudionika. Samo 4,3 \% studenata se uopće ne slaže s tom tvrdnjom, a 1,4\% se uglavnom ne slaže. U zdravstvena istraživanja o cijepljenju vjeruje 55,5 \% ukupnog broja ispitanika te je sličan stav studenata i o zdravstvenim istraživanjima o cjepivima. Na tu je tvrdnju 53,4 \% studenata odgovorilo da se u potpunosti slaže.

Na pitanje iz anketnog upitnika da daju prijedlog kako povećati cijepni obuhvat u RH, 177 studenata ( $63 \%$ ) odgovorilo je da bi trebalo više informirati i educirati opću populaciju o cijepljenju. Nekolicina studenata odgovorila je kako bi uveli obveznu potvrdu o cijepljenju prije ulaska u školu ili vrtić, a podjednaki broj odgovora bio je i za to da se poboljša komunikacija između liječnika i pacijenta. Nešto manji broj studenata odgovorio je kako bi se trebala davati odšteta u slučaju nuspojava. Najmanje odgovora dobile su tvrdnje kako je potrebno da cijepljenje postane neobvezno i da bi trebala bolja edukacija zdravstvenih djelatnika.

\section{Opći stav o cijepljenju}

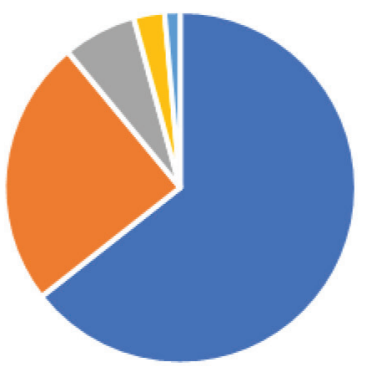

- pozitivan = uglavnom pozitivan = niti pozitivan niti negativan = uglavnom negativan " negativan 


\section{Tablica 3. Likertova skala stavova studenata o cjepivima i cijepljenju}

\begin{tabular}{|c|c|c|c|}
\hline & & BROJ SUDIONIKA & $\%$ \\
\hline \multirow{6}{*}{ Cjepiva su korisna. } & Uopće se ne slažem & 3 & 1,1 \\
\hline & Uglavnom se ne slažem & 5 & 1,8 \\
\hline & Ne mogu se odlučiti & 21 & 7,5 \\
\hline & Uglavnom se slažem & 60 & 21,4 \\
\hline & U potpunosti se slažem & 192 & 68,3 \\
\hline & Ukupno & 281 & 100 \\
\hline \multirow{6}{*}{ Cjepiva su sigurna. } & Uopće se ne slažem & 7 & 2,5 \\
\hline & Uglavnom se ne slažem & 12 & 4,3 \\
\hline & Ne mogu se odlučiti & 45 & 16 \\
\hline & Uglavnom se slažem & 140 & 49,8 \\
\hline & U potpunosti se slažem & 77 & 27,4 \\
\hline & Ukupno & 281 & 100 \\
\hline \multirow{6}{*}{ Cjepiva imaju nizak rizik teških nuspojava. } & Uopće se ne slažem & 10 & 3,6 \\
\hline & Uglavnom se ne slažem & 19 & 6,8 \\
\hline & Ne mogu se odlučiti & 72 & 25,6 \\
\hline & Uglavnom se slažem & 95 & 33,8 \\
\hline & U potpunosti se slažem & 85 & 30,2 \\
\hline & Ukupno & 281 & 100 \\
\hline \multirow{6}{*}{ Bojim se mogućih nuspojava cijepljenja. } & Uopće se ne slažem & 79 & 28,1 \\
\hline & Uglavnom se ne slažem & 91 & 32,4 \\
\hline & Ne mogu se odlučiti & 38 & 13,5 \\
\hline & Uglavnom se slažem & 47 & 16,7 \\
\hline & U potpunosti se slažem & 26 & 9,3 \\
\hline & Ukupno & 281 & 100 \\
\hline \multirow{6}{*}{ Cijepljenje djece mora ostati obvezno. } & Uopće se ne slažem & 12 & 4,3 \\
\hline & Uglavnom se ne slažem & 4 & 1,4 \\
\hline & Ne mogu se odlučiti & 18 & 6,4 \\
\hline & Uglavnom se slažem & 41 & 14,6 \\
\hline & U potpunosti se slažem & 206 & 73,3 \\
\hline & Ukupno & 281 & 100 \\
\hline \multirow{6}{*}{$\begin{array}{l}\text { Vjerujem u rezultate zdravstvenih istraživanja o } \\
\text { cijepljenju. }\end{array}$} & Uopće se ne slažem & 6 & 2,1 \\
\hline & Uglavnom se ne slažem & 8 & 2,8 \\
\hline & Ne mogu se odlučiti & 41 & 14,6 \\
\hline & Uglavnom se slažem & 70 & 24,9 \\
\hline & U potpunosti se slažem & 156 & 55,5 \\
\hline & Ukupno & 281 & 100 \\
\hline \multirow{6}{*}{$\begin{array}{l}\text { Vjerujem u rezultate zdravstvenih istraživanja o } \\
\text { cjepivima. }\end{array}$} & Uopće se ne slažem & 6 & 2,1 \\
\hline & Uglavnom se ne slažem & 14 & 5 \\
\hline & Ne mogu se odlučiti & 37 & 13,2 \\
\hline & Uglavnom se slažem & 74 & 26,3 \\
\hline & U potpunosti se slažem & 150 & 53,4 \\
\hline & Ukupno & 281 & 100 \\
\hline
\end{tabular}




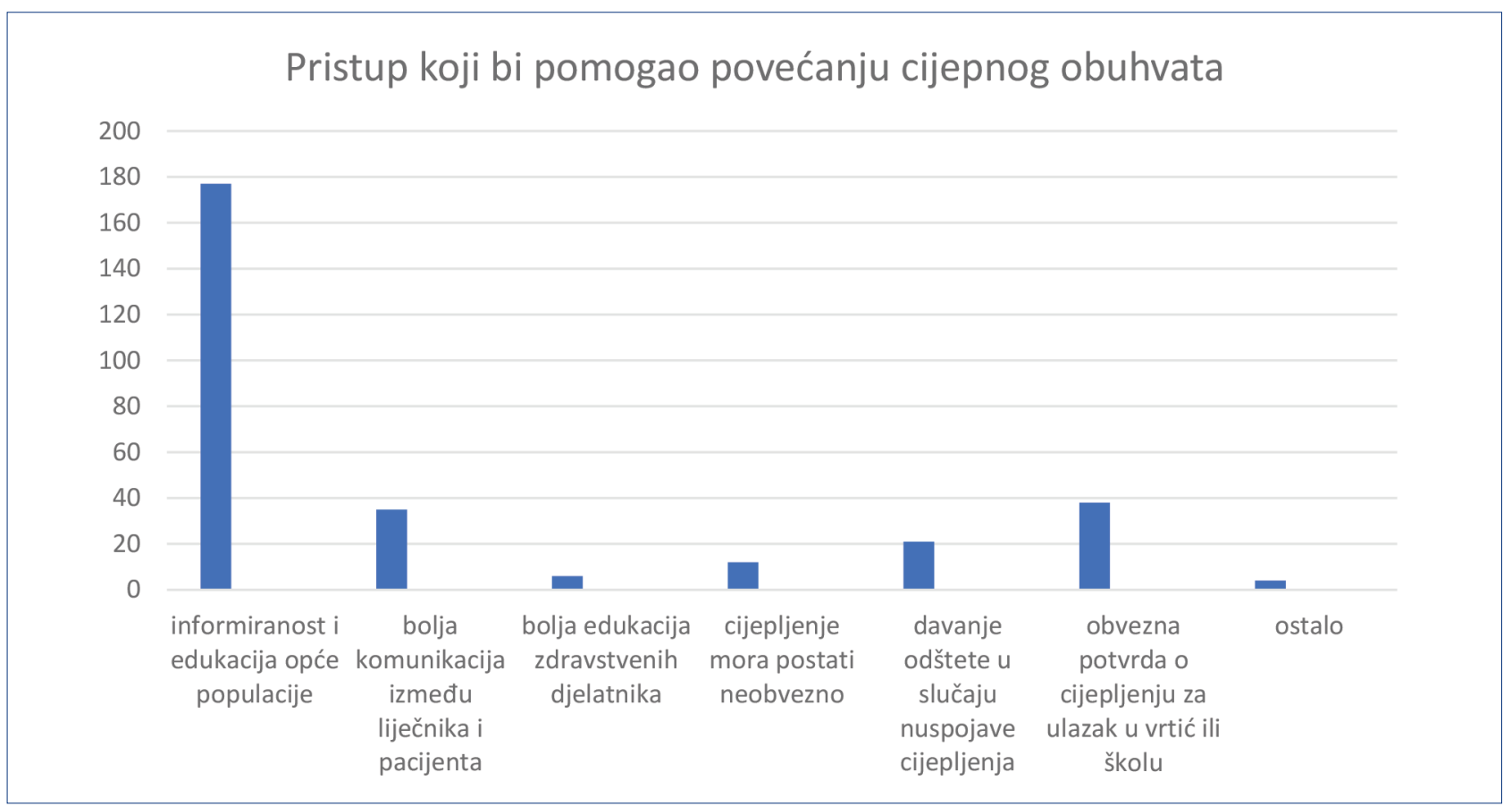

Slika 4. Prijedlog pristupa koji bi pomogao povećanju cijepnog obuhvata

\section{Rasprava}

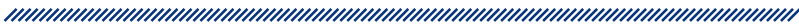

Stavovi studenata Zdravstvenog veleučilišta o cijepljenju vrlo su važna karika u osiguranju zadovoljavajuće procijepljenosti populacije. Kao budući zdravstveni djelatnici, od njih se očekuje da ovu temu gledaju s pozitivnog gledišta te da svoje stavove temelje na medicinskim dokazima. Svjedoci smo sve većeg pada postotka procijepljenosti te stvaranja i jačanja antivakcinalnog pokreta, stoga je važno da budući znanstveni radnici imaju dobre temelje u borbi protiv negativnih razmišljanja o cijepljenju. Uloga studenata Zdravstvenog veleučilišta, dijelom budućega medicinskog osoblja, važna je u edukaciji populacije o važnosti cijepljenja djece kao i odraslih ako je potrebno.

U istraživanju je sudjelovao 281 student Zdravstvenog veleučilišta, većina je studenata sestrinstva i sanitarnog inženjerstva, dok su se studenti ostalih smjerova odazvali u manjem broju. Također, nešto je veći postotak studenata s prve godine, ali su razlike u postocima minimalne.

Pokazalo se da studenti imaju pozitivan stav o cijepljenju, što je očekivano s obzirom na znanje koje imaju o toj temi. Nekolicina studenata ima negativan $(1,4 \%)$ ili uglavnom negativan (2,8 \%) stav o cijepljenju, što je zanemarivo s obzirom na ukupni postotak ispitanih studenata. Takav stav mogao bi se pripisati utjecaju interneta i raznih medija koji propagiraju loše strane cijepljenja i prestanak njegova provođenja. Provela su se razna istraživanja u sklopu završnih radova studenata te mnoga dokazuju kako studenti najviše informacija o cijepljenju primaju preko interneta (68,6 \% informacija). ${ }^{11,13}$ Unatoč internetu i medijima te njihovu negativnom utjecaju na sve oko nas, većina studenata ima pozitivan stav o cijepljenju, što se također slaže s drugim istraživanjima. Student Zdravstvenog veleučilišta proveo je istraživanje uspoređujući znanje i stavove studenata Zdravstvenog veleučilišta i Agronomskog fakulteta te je postotak studenata koji imaju pozitivan stav također visok. ${ }^{11}$ Takvi stavovi studenata protežu se i izvan granica Hrvatske. Slično istraživanje provedeno je i u Srbiji te također pokazuje uglavnom pozitivan stav studenata. ${ }^{12}$

Kod tvrdnje „Cjepiva su korisna” više od 50 \% ispitanika odgovorilo je da se u potpunosti slažu s tvrdnjom. Također, postotak negativnih stavova vrlo je nizak i zanemariv te ponovno iznosi $1 \%$ (tablica 4 ).

Tvrdnja „Cjepiva su sigurna” ipak je dovela do drugačijih razmišljanja. lako i dalje uglavnom pozitivnih stavova, studenti su dali do znanja da im je mišljenje o toj tvrdnji 
neodređeno. Naime, studenata koji imaju u potpunosti pozitivno mišljenje o ovoj tvrdnji bilo je svega $27,4 \%$. Polovica ispitanih $(49,8 \%)$ ipak se odlučila za uglavnom pozitivan stav, što je i dalje zadovoljavajući ishod. Neodlučnih studenata bilo je nešto više nego kod prethodne tvrdnje (16\%). Na Medicinskom fakultetu provedeno je istraživanje među roditeljima koje je provodila studentica tog fakulteta te je na pitanje ovog tipa dobila manje pozitivnih odgovora. Ispitani roditelji bili su neodlučni oko odgovora ili su se djelomično slagali, što pokazuje da bi budući rad studenata Zdravstvenog veleučilišta mogao pozitivno utjecati na stavove drugih. ${ }^{5}$

Vrlo pozitivan stav studenata i vjeru u medicinska istraživanja te ono što su odabrali biti u budućnosti pokazuje tvrdnja "Cjepiva imaju nizak rizik teških nuspojava”. Upravo ova tvrdnja predmet je sumnje svih studenata kada je tema cijepljenje. Podjednak je postotak odgovora studenata koji se u potpunosti slažu te onih koji su neodlučni oko ovog pitanja. 30,2 \% studenata u potpunosti se slaže s ovom tvrdnjom, 33,8 \% se uglavnom slaže te je 25,6\% studenata neodlučno. Također, većina studenata ne slaže se s tvrdnjom da se boje mogućih nuspojava cijepljenja iako postoji nešto veći postotak onih koji se boje (9,3\%).

Najvažnije pitanje koje se proteže kako u istraživanjima tako i u medijima, pitanje je obveznog cijepljenja. Sudionici ovog istraživanja odgovorili su vrlo uvjerljivo na ovu tvrdnju te $73,3 \%$ studenata smatra da cijepljenje mora ostati obvezno. Od 281 ispitanika samo je 12 odgovorilo da se uopće ne slaže s tom tvrdnjom. Ovakav ishod također bilježe druga istraživanja. Već spomenuti student Zdravstvenog veleučilišta na sličnom istraživanju ispitao je 251 studenta te je rezultat bio da $87,2 \%$ studenata smatra cijepljenje obveznim. ${ }^{11}$

Minimalna razlika u odgovorima bila je na tvrdnjama „Vjerujem u istraživanja o cijepljenju” i „Vjerujem u istraživanja o cjepivima". Ove tvrdnje postavili smo u istraživanje zato što su upravo one jedne od argumenata pokreta protiv cijepljenja. Mnogi pripadnici takvih pokreta zastupaju mišljenje da cjepiva nisu dovoljno istražena kao ni njihove posljedice te nas je zanimalo mišljenje budućih zdravstvenih radnika. Očekivano, studenti su imali pozitivno mišljenje te je postotak u obje tvrdnje veći od $50 \%$ za ocjenu „U potpunosti se slažem”.

Četvrti, ujedno posljednji dio ankete tražio je prijedlog sudionika istraživanja koji bi pomogao povećanju cijepnog obuhvata s obzirom na to da se taj postotak iz godine u godinu smanjuje. Najveći postotak, čak $63 \%$ studenata, odgovorio je kako bi se cijepni obuhvat po- većao boljim informiranjem i edukacijom opće populacije o cijepljenju. Mnogi studenti smatraju kako bi jedan od načina trebao biti i obvezna potvrda o cijepljenju za ulazak u vrtić ili školu te bolja komunikacija između liječnika i pacijenta. Informiranje i edukacija ljudi izravno je povezana s komunikacijom između liječnika i pacijenta, što dovodi do zaključka da ljudi imaju negativna mišljenja te padaju pod utjecaj medija zbog manjka znanja i komunikacije sa stručnim ljudima.

Tvrdnje oko kojih se postotak odgovora studenata nešto više razlikovao bile su o niskom riziku teških nuspojava te o strahu od mogućih nuspojava. Kod tvrdnje da cjepiva imaju nizak rizik teških nuspojava nešto se veći postotak studenata nije mogao odlučiti slaže li se ili ne s tom tvrdnjom, dok je nekolicina studenata imala uglavnom negativan stav. Tvrdnja o strahu od mogućih nuspojava također je nekolicinu studenata navela na razmišljanje. Ovdje je veći postotak studenata rekao da se boji mogućih nuspojava nego što je bilo neodlučnih studenata.

\section{Zaključak}

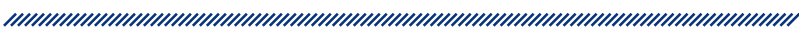

Analizom dobivenih podataka možemo zaključiti da većina studenata Zdravstvenog veleučilišta, neovisno o smjeru i godini studiranja, ima pozitivan stav o cijepljenju.

Isto tako, većina je studenata mišljenja da su cjepiva korisna i sigurna, stoga zaključujemo da je dosadašnja edukacija na veleučilištu zadovoljavajuća te je prenijela i pružila medicinski utemeljene dokaze, koji su pomogli u formiranju pozitivnog stava o cijepljenju.

Svi studenti jednoglasno smatraju da cijepljenje mora ostati obvezno, što se također može pripisati edukaciji na ZVU-u. Osim obveznog cijepljenja, svi su dali do znanja da vjeruju medicinskoj struci i istraživanjima o cijepljenju i cjepivima.

Za povećanje cijepnog obuhvata u Hrvatskoj te pomaganju smanjivanja negativnog trenda opadanja postotka procijepljenosti studenti su u većini dali prijedlog da se poboljša dostupnost i komunikacija između liječnika i pacijenta te da se samim tim populacija bolje educira i informira.

Ipak, istraživanja o ovako opširnoj temi zahtijevaju nešto veći broj ispitanika. Stoga bi u budućnosti bilo dobro da se u istraživanje uključi više ljudi kako bi uzorak bio što reprezentativniji, a rezultati vjerodostojniji. 


\section{Referencije}

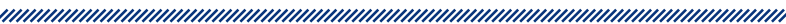

1. Valek I, Milas J, Šimović G, Ćavar LJ, Gavran M. Kretanje zaraznih bolesti protiv kojih se provodi obvezno cijepljenje na području grada Osijeka. Hrvatski časopis za javno zdravstvo. 2008; 4 (15).

2. Cijepljenje. Zavod za javno zdravstvo Dubrovačko-neretvanske županije. Dostupno na: https://www.zzjzdnz.hr/ hr/usluge/cijepljenje (pristupljeno: 30.6.2020.).

3. Nakić V. Stanje procijepljenosti protiv dječjih zaraznih bolesti u Krapinsko-zagorskoj županiji u razdoblju od 2000 - 2009. godine. Hrvatski časopis za javno zdravstvo. 2011; 7 (26).

4. Bela Kancir S. Cijepljenje - vrste cijepljenja i primjena. Vaše zdravlje. 2002. Dostupno na: https://www.vasezdravlje.com/djecje-zdravlje/cijepljenje-vrste-cjepivai-primjena (pristupljeno: 1.7.2020.).

5. Kulić I. Stavovi roditelja prema cijepljenju vlastite djece [završni rad]. Zagreb: Medicinski fakultet; 2015.

6. Cjepiva i cijepljenje. Stoljetna ljudska težnja. Narodni zdravstveni list. Dostupno na: http://www.zzjzpgz.hr/ nzl/98/prevencijazb.htm (pristupljeno: 1.7.2020.).
7. Riedel S. Edward Jenner and the history of smallpox and vaccination. Baylor University Medical Center. 2005;18(1): 21 - 25. Dostupno na: https://www.ncbi.nlm.nih.gov/ pmc/articles/PMC1200696/ (pristupljeno: 2.7.2020.).

8. Zakon o zaštiti pučanstva od zaraznih bolesti NN 130/17.

9. Nuspojave cijepljenja u Hrvatskoj u 2018. godini. Hrvatski zavod za javno zdravstvo. 2019. Dostupno na: https:// www.hzjz.hr/wp-content/uploads/2019/10/Nuspojavecijepljenja-u-Republici-Hrvatskoj-u-2018.-godini.pdf (pristupljeno: 10.8.2020.).

10. Hrvatsko epidemiološko društvo. Struka zagovara redovito provođenje cijepljenja. Dostupno na: http://www. halmed.hr/fdsak3jnFsk1Kfa/novosti/Cijepljenje_HED_ HID.pdf (pristupljeno: 30.6.2020.).

11. Milobara S. Znanje i stavovi studenata Zdravstvenog veleučilišta i Agronomskog fakulteta o cijepljenju [završni rad]. Zagreb: Zdravstveno veleučilište; 2019.

12. Cvjetković JS, Jeremić LjV, Tiosavljević VD. Knowledge and Attitudes Toward Vaccination: A Survey of Serbian Students. Journal of infection and public health. 2017; 10 (5): 649-656

13. Maričić T. Stavovi studenata Veleučilišta u Bjelovaru o cijepljenju djece [završni rad]. Bjelovar: Veleučilište u Bjelovaru; 2019. 


\section{ATTITUDES OF STUDENTS OF THE UNIVERSITY OF APPLIED HEALTH SCIENCES TOWARDS VACCINATION}

\author{
1 Anna Pierobon \\ 2 Mirjana Lana Kosanović Ličina \\ 1 University of Applied Health Sciences, Mlinarska cesta 38, \\ Zagreb \\ 2 Andrija Stampar Teaching Institute of Public Health, \\ Mirogojska cesta 16, Zagreb
}

\section{Summary}

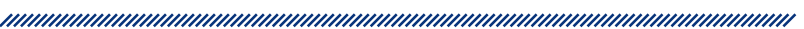

Immunoprophylaxis is the artificial creation of immunity. Immunoprophylaxis is performed in two ways, namely vaccination (active immunization) and immunoglobulin intake (passive immunization). Active immunization, or vaccination, is a procedure of introducing a specific antigen into the body that stimulates the development of a specific defense against a specific cause of an infectious disease. Vaccination has proven to be the most successful intervention of modern medicine and is a fundamental human right. Vaccination has significantly reduced morbidity and mortality in the population worldwide. In Croatia, vaccination of children and adults is carried out according to the Compulsory Vaccination Program. Starting from birth, vaccines are given at certain periods of life, and some are given in single and some in multiple doses. Vaccination in Croatia is at a satisfactory level despite the declining vaccination rate in the last few years. The aim and purpose of this research was to see the attitudes of students of the University of Applied Health Sciences towards vac-

cination. The sample contained 281 respondents. Respondents were students of all study programmes, on all three years of studies at the University of Applied Health Sciences (Environmental Health Engineering, Nursing, Medical Laboratory Diagnostics, Radiological Technology, Occupational Therapy). The results of the research showed that all students have a positive attitude towards vaccination, which is a good result considering that all study programs educate health professionals and that their education about vaccination is at a high level.

Keywords: vaccination, vaccines, vaccination coverage, attitudes of students 